\title{
Effect of high protein supplementation on growth and nutrient digestibility of broiler
}

\author{
Hossain MA ${ }^{1}$, I Zulkifli ${ }^{2}$ and AF Soleimani ${ }^{2}$
}

${ }^{1}$ Department of Dairy \& Poultry Science, Chittagong Veterinary and Animal sciences University, Khulshi, Chittagong, Bangladesh; ${ }^{2}$ Institute of Tropical Agriculture; Universiti Putra Malaysia; 43400 UPM, Serdang, Malaysia

\begin{abstract}
This study was undertaken to compare the growth performance and nutrient digestibility (energy, protein and amino acid) of broilers fed diets containing only vegetable protein (soybean) with birds that received Pro-EL as protein supplement in their diets. Day-old male broiler chicks $(n=60$; Cobb 500$)$ were randomly distributed into 2 dietary treatment groups, namely control $\left(T_{1}\right)$ and supplemented $\left(T_{2}\right)$ diets, with 5 birds per replication in a CRD. Birds had a free access to iso-caloric and iso-nitrogenous starter diets in cages up to $21 \mathrm{~d}$. The results of FI, LW, LWG and FCR of broilers up to 21 days were poorer $(P<0.01)$ on $\mathrm{T}_{2}$ diet than the broilers fed on $\mathrm{T}_{1}$ diet. The ileal nutrient digestibility of GE and $\mathrm{CP}$ was identical $(P>0.05)$, but the majority of the AAs digestibility values were influenced $(P<0.05 ; P<0.01)$ by treatments except for Gly, Thr, Cys, Val, Ile, Leu, and Phe. The digestibility of Asp, His, Arg, Ala, Pro, Ser, Glu, Tyr and Lys was impaired $(P<0.05 ; P<0.01)$ in the $T_{2}$ diet compared to $T_{1}$ diet except for Met, which was improved $(P<01)$ in $\mathrm{T}_{2}$ diet. It can be concluded that the negative response of broilers fed on protein supplemented diet might arise from the reduced nutrient digestibility of the diet.
\end{abstract}

Key words: growth, pro-el, nutrient digestibility, broiler chicken

Bangladesh Animal Husbandry Association. All rights reserved.

Bang. J. Anim. Sci. 2017. 46 (1): 44-50

\section{Introduction}

Protein is an expensive element and indelibly requires to formulate diet, and to meet the essential nutrient requirement of the broiler chickens. It is well-recognized that greater portion of costs associated with poultry production involves meeting the requirements of protein or amino acids (AAs) of the birds (May et al., 1998; Corzoet al., 2004). It is reported that protein requirements incur $45 \%$ of the total cost of poultry production (Ahmad et al., 2006). Deficiency of protein and amino acids in poultry diet can adversely affect their optimum growth and development (Awad et al., 2016). Moreover, proteins play a crucial role in structural and protective tissues in the body and are also important in enzymes and tissue functions (NRC, 1994). However, it can be assumed that broiler diets supplemented with the high protein sourced ingredient might be potential to ensure the better productivity of the broiler chickens. Moreover, the supplementation of a novel protein ingredient into broiler diet might reduce the lacks and gaps of protein requirement as well as the feed cost of rearing broiler chicken under hot humid tropical condition. For this reason, poultry scientists and feed formulators are exploring cheap sources of feed ingredients and feed supplements to manufacture the quality poultry diet. In this regard, protein supplement such as Pro-EL can be incorporated into poultry diet as a rich source of protein ingredient to enhance the quality and quantity of diet. This ingredient is available in the commercial market as a synthetic form or protein supplement and cheaper in cost, which contains more than $80 \%$ protein with a good profile of both essential and non-essential amino acids, as observed by our lab analytical process.

The introduction of this novel protein supplement (Pro-EL) into poultry diet might be beneficial to be used as a rich source of protein to meet the actual protein requirement and enhanced production. However, the growth responses of broiler chickens are the key performance indicator, which can be attained or assessed by feeding birds with a different sort of feedstuffs or diets, available in the nature or commercially.

*Corresponding author: mhossainmu@yahoo.com 
Basically, the nutritional value of diets fed to chicken can be evaluated by their productivity and nutrient digestibility. Besides, the knowledge of the digestibility of feed ingredients is the basic requirement to formulate the balanced diet of chicken. Furthermore, determining feed nutrient digestibility is also considered as an important parameter in evaluating the nutrient adequacy or availability and efficiency of the feedstuffs (Noreen, 2006). However, the information on nutrient digestibility of all feedstuffs available in the nature is limited. Without accurate digestible data of the available feedstuffs, diet formulators, researchers and nutritionists might run a risk of over-fortification, which can raise the cost of feeding the birds, or under-fortification might results in reduced growth rate or poor performance of the birds. However, there is a lack of information regarding the nutritional value and digestibility of many unconventional feed resources such as novel synthetic ingredients, crab meal and there is a lack of inconsistency in the methods used to determine digestibility (Applegate et al., 2008; Garcia et al., 2007). Considering this view, the present study was undertaken to investigate the gross responses and the apparent ileal digestibility of gross energy (GE), crude protein (CP) and amino acids (AAs) of protein supplemented diet (Pro-EL) diets fed the broiler chickens.

\section{Materials and Methods}

\section{Animal Husbandry and experimental design}

A total of sixty (Cobb 500) day-old male broiler chicks were procured from a local commercial hatchery to conduct this experiment up to 21 days. The chicks were weighed on receipt, and then equally assigned to two dietary treatment groups $\left(T_{1}\right.$ and $\left.T_{2}\right)$, each diet replicated 6 times with five birds per replication in a completely randomized block design (CRD). All the chicks were allotted into 12 battery cages within an open-sided housing condition. The chicks were fed a broiler starter diet from day 1 to $21 \mathrm{~d}$ (Table 1). The following two diets were used: (i) standard corn-soybean based broiler diet (control, $\mathrm{T}_{1}$ ) and (ii) broiler diet containing15\% Pro-EL ( $T_{2}$ or test diet). The ingredient and nutrient compositions of $T_{1}$ and $T_{2}$ were shown in Table 1. Both diets were iso-caloric and iso- nitrogenous in nature and contained titanium dioxide $\left(\mathrm{TiO}_{2}\right)$ as marker to enable assessment of nutrient digestibility ( $G E, C P, A A s)$. Birds had a free access to feed (mash) and water entire the trial period.

Table 1. Ingredients and nutrient composition of experimental diets

\begin{tabular}{|c|c|c|}
\hline \multirow{2}{*}{$\begin{array}{l}\text { Ingredient } \\
\text { composition (\%) }\end{array}$} & \multicolumn{2}{|c|}{ Treatment } \\
\hline & $\mathbf{T}_{1}$ & $\mathbf{T}_{2}$ \\
\hline Corn & 53.37 & 61.50 \\
\hline $\begin{array}{l}\text { Protein supplement } \\
\text { (Pro-EL) }\end{array}$ & 0.00 & 15.00 \\
\hline Soybean meal & 37.20 & 12.52 \\
\hline Palm oil & 4.50 & 2.30 \\
\hline DCP & 2.00 & 2.00 \\
\hline Limestone & 1.40 & 1.40 \\
\hline Common salt & 0.10 & 0.10 \\
\hline Sodium sulphate & 0.40 & 0.40 \\
\hline Choline $\mathrm{Cl}-70 \%$ & 0.05 & 0.15 \\
\hline Sand & 0.00 & 4.00 \\
\hline Vitamin- premix ${ }^{1}$ & 0.05 & 0.05 \\
\hline Mineral- premix ${ }^{1}$ & 0.10 & 0.10 \\
\hline L-Lysine & 0.48 & 0.31 \\
\hline DL-Methionine & 0.25 & 0.00 \\
\hline L-Threonine & 0.10 & 0.17 \\
\hline \multicolumn{3}{|l|}{$\begin{array}{l}\text { Nutrient composition } \\
(\%) \text { (calculated } \\
\text { value) }\end{array}$} \\
\hline ME (MJ/kg) & 12.71 & 12.71 \\
\hline $\mathrm{CP}$ & $22.00(23.65)$ & $22.00(23.80)$ \\
\hline $\mathrm{CF}$ & 2.30 & 2.70 \\
\hline $\mathrm{Ca}$ & 0.95 & 0.94 \\
\hline Available P & 0.46 & 0.45 \\
\hline Lysine & $1.45(1.9)$ & $1.44(1.4)$ \\
\hline Methionine & $0.54(0.6)$ & $0.53(0.67)$ \\
\hline Threonine & 0.94 & 0.94 \\
\hline
\end{tabular}

[ $T_{1}$ diet refers to control or basal diet whereas $T_{2}$ is test diet having $15 \%$ protein supplement, i.e Pro-EL; Figures inside the bracket only indicate analyzed value whereas figures outside the bracket indicate calculated values; ${ }^{1}$ Provided per $\mathrm{kg}$ of diet $(\mathrm{mg})$ : vitamin A (as all-trans retinol), $3.6 \mathrm{mg}$; cholecalciferol, $0.09 \mathrm{mg}$; vitamin $\mathrm{E}$ (as datocopherol), $44.7 \mathrm{mg}$; vitamin $\mathrm{K} 3,2 \mathrm{mg}$; thiamine, 2 $\mathrm{mg}$; riboflavin, $6 \mathrm{mg}$; pyridoxine hydrochloride, 5 $\mathrm{mg}$; vitamin B12, $0.2 \mathrm{mg}$; biotin, $0.1 \mathrm{mg}$; niacin, 50 $\mathrm{mg}$; D- calcium pantothenate, $12 \mathrm{mg}$; folic acid, 2 $\mathrm{mg}$; $\mathrm{Mn}, 80 \mathrm{mg}$; $\mathrm{Fe}, 60 \mathrm{mg}$; $\mathrm{Cu}, 8 \mathrm{mg}$; I, $1 \mathrm{mg}$; Co, $0.3 \mathrm{mg}$ and Mo, $1 \mathrm{mg}$.] 
Hossain et al. (2017) Bang. J. Anim. Sci. 46 (1):44-50

\section{Data collection}

Live weight, feed intake and feed conversion ration were calculated weekly, to assess the gross responses of the broiler chicks. Three chicks from each replicate cage on day 21 , were selected randomly, weighed and killed by humanely to collect ileal digesta contents from the ileum of the birds. Collected digesta were pooled by pen in a plastic container and later dried by freeze -dryer machine. The dried samples were ground to pass through a $0.5 \mathrm{~mm}$ sieve, and stored in airtight containers at $-20^{\circ} \mathrm{C}$ for chemical analyses.

\section{Composition of Pro-EL ingredient (analyzed value)}

It's a synthetic protein supplement which contains ME, $3200 \mathrm{Kcal} / \mathrm{kg}, \mathrm{CP}, 84.12 \%$, NPN, $3.42 \%$, lysine $4.6 \%$, methionine $3.0 \%$, cysteine $0.013 \%$, leucine $5.3 \%$, histidine, $1.27 \%$, threonine $2.73 \%$, valine $3.3 \%$, glycine $2.26 \%$, arginine $4.3 \%$.

\section{Chemical analyses}

The starter diets and digesta samples were analyzed for GE, CP and AA digestibility. Samples were dried at $105{ }^{\circ} \mathrm{C}$ in a drying oven for $24 \mathrm{~h}$ for dry matter (DM) determination. The titanium dioxide $\left(\mathrm{TiO}_{2}\right)$ concentrations in the diets and digest samples were measured after ashing the samples and treating the ash with boiling 7.4 M sulphuric acid according to the method of Short et al. (1996). Gross energy content of diets and ileal digesta were determined using an IKA bomb calorimeter (IKA-WERKE, C7000, Staufen, Germany). Nitrogen content of the samples was determined by Kjeldahl method using standard laboratory procedures (AOAC, 2000). Crude protein $(\mathrm{CP})$ equivalent was calculated as $\mathrm{N}(\%)$ $\times 6.25$.

The AAs concentrations of diets and ileal digesta samples were analyzed following the procedure as described by Strydom and Cohen(1994), using the pre-column derivatization method (AccQ Tag, Waters, Milford, Ma, USA), high performance liquid chromatography (HPLC). Cysteine and methionine were analyzed as cysteic acid and methionine sulfone by oxidation with performic acid for $16 \mathrm{~h}$ at $4^{\circ} \mathrm{C}$, and neutralization with hydrobromic acid before hydrolysis. The apparent ileal digestibility coefficient of nutrients (GE, CP and AAs) was calculated using the following equations:

a) Digestibility coefficient for diet

$$
=1-\frac{\text { digesta nutrient }(\mathrm{g} / \mathrm{kg}) / \text { digesta } \mathrm{TiO}_{2}(\mathrm{~g} / \mathrm{kg})}{\operatorname{diet} \text { nutrient }(\mathrm{g} / \mathrm{kg}) / \operatorname{diet} \mathrm{TiO}_{2}(\mathrm{~g} / \mathrm{kg})}
$$

\section{Statistical analyses}

All collected data were statistically analyzed using Minitab software (Minitab Version 16, 2000). The data were analyzed using one-way ANOVA with diet as factor. The significance of differences between means was determined by Fisher's least significant difference $P \leq .05$.

\section{Results}

The results of gross responses of broilers denote that FI, LW, LWG and FCR fed supplemented diet $\left(T_{2}\right)$ were poorer $(P<0.01)$ than the responses of broiler fed control diet $\left(T_{1}\right)$ as shown below in Table 2. The apparent ileal digestibility values of $\mathrm{CP}$ and GE were not influenced $(\mathrm{P}>0.05)$ by dietary treatment (Table 3 ). The ileal digestibility values of most of the AAs were influenced significantly $\quad(P<0.05 ; \quad P<0.01)$ by dietary treatment measured in this study (Table 3 ). The ileal digestibility values of Gly, Thr, Cys, Val, Ile, Leu and Phe were not influenced $(P>0.05)$ by dietary treatment. The ileal digestibility values of Asp, His, Arg, Ala, Pro, Ser, Glu, Tyr and Lys were decreased $(P<0.05 ; P<0.01)$ in the supplemented diet $\left(T_{2}\right)$ compared to basal diet $\left(T_{1}\right)$ except for Met. Only the digestibility of Met was improved $(P<0.01)$ in the birds fed supplemented diet $\left(T_{2}\right)$. 
High protein supplementation in broiler

Table-2. Feed intake (FI), live weight (LW), live weight gain (LWG) and feed conversion ratio (FCR) of broiler chickens fed protein supplemented diet from d1-21 days

\begin{tabular}{|c|c|c|c|c|c|}
\hline \multirow[t]{2}{*}{ Parameters } & \multirow[t]{2}{*}{ Age (days) } & \multicolumn{2}{|c|}{ Treatment } & \multirow[t]{2}{*}{ Pooled SEM } & \multirow[t]{2}{*}{ P-values } \\
\hline & & $\mathbf{T}_{1}$ & $\mathbf{T}_{2}$ & & \\
\hline \multirow{3}{*}{ FI $(g / b)$} & $1-14$ & $547.33^{\mathrm{a}}$ & $394.00^{b}$ & 8.500 & 0.01 \\
\hline & $1-21$ & $1199.17^{a}$ & $830.17^{b}$ & 15.242 & 0.01 \\
\hline & $1-14$ & $416.33^{a}$ & $246.83^{b}$ & 5.112 & 0.01 \\
\hline \multirow[t]{2}{*}{$\operatorname{LW}(\mathrm{g} / \mathrm{b})$} & $1-21$ & $889.33^{a}$ & $475.00^{b}$ & 18.142 & 0.01 \\
\hline & $1-14$ & $371.67^{a}$ & $202.00^{b}$ & 5.113 & 0.01 \\
\hline \multirow[t]{2}{*}{ LWG (g/b)) } & $1-21$ & $844.67^{a}$ & $430.17^{b}$ & 18.161 & 0.01 \\
\hline & $1-14$ & $1.42^{\mathrm{b}}$ & $1.95^{\mathrm{a}}$ & 0.018 & 0.01 \\
\hline FCR & $1-21$ & $1.48^{\mathrm{b}}$ & $1.96^{\mathrm{a}}$ & 0.045 & 0.01 \\
\hline
\end{tabular}

[Each value refers to mean value of six replicates consisting of five birds per replicate cage from d1 to 21 ; ${ }^{a b}$ Means bearing uncommon superscripts within a row are significantly different at $* * P<0.01$; SEM, Pooled standard error of mean; $T_{1}$, basal diet while $T_{2}$, supplemented diet].

\section{DISCUSSION}

Growth performance in broiler chickens has been regarded as the primary criterion for determining the feed nutrient requirements because the broiler chick is an ideal research tool with a limited nutrient store, high nutrient demand and rapid growth rate (Ammerman, 1995). In this study, overall growth responses of the broilers were influenced adversely by feeding supplemented $\left(T_{2}\right)$ diet. The reduced performance of broilers on supplemented diet could be due to poor feed intake of the birds as observed in our study. The poor feed intake of broilers on $T_{2}$ diet could also be caused by poor weight gain of the birds and the consequent lower nutritional requirement (Hossain et al., 2016). Though palatability test of the diet was not done, but it can be assumed that the less palatability and poor nutrient (AAs) digestibility of the diet could be reasons which might influence the feed intake and growth performance of the birds (Jackson et al., 1982; Mahmoudnia et al., 2011). It is reported that the AAs imbalances in diets decreased the biological value and feed intake of the diets (Jackson et al., 1982).
Besides, other factors such as organoleptic traits (e.g colour, smell, odour, flavor, taste and texture) of diet might also affect the feed ingestion and feed regulation of broiler chickens (Cruze et al., 2005). Further, dietary composition and sources of protein use in the practical diet could also influence the feed intake and feed preference of broiler chicken (Hossain, 2013). However, it is obvious from the current study that broilers fed protein supplemented $\operatorname{diet}\left(\mathrm{T}_{2}\right)$ grew poorly, most probably as a result of reduced feed consumption, inferior FCR and poor nutrient (AAs) digestibility of the birds. The impaired FCR of birds on $\mathrm{T}_{2}$ diet indicates that the broilers are less efficient to convert this feed to meat more rapidly than the birds fed on control diet (Hossain et al., 2011). Apart from these, the impaired amino acids (AAs) digestibility of the supplemented diet might be another reason for the poor growth responses of the birds as is evidence from our present study.

Our results further revealed that test diets had no influence on the macro-nutrient (energy and protein) digestibility, but micro-nutrient, particularly AAs digestibility values were influenced significantly in this study. The digestibility values of Asp, His, Arg, Ala, Pro, Ser, 
Glu, Tyr and Lys were found to be reduced in the supplemented diet $\left(\mathrm{T}_{2}\right)$ compared to basal diet $\left(T_{1}\right)$ except for only Met. Although no synthetic Met was added into the diet, the Met digestibility was found to be increased in the supplemented diet. The higher content of Met in the supplemented diet might influence the improved digestibility of Met. Apart from the Met digestibility, the reason for the reduced digestibility of $A A$ on supplemented $\operatorname{diet}\left(T_{2}\right)$ is not obvious, but it can be said that the quality and quantity of the protein of the test diet possibly become a factor which can cause a difference in digestibility between two diets (Hossain et al., 2014). Further, the reduced AAs digestibility of birds on supplemented diet might be due to less absorption, utilization and assimilation by the intestinal tissue of the broiler chickens (Hossain et al., 2015).

In fact, the protein requirement for poultry is actually a requirement for amino acids (NRC, 1994). It is reported that the quality of dietary proteins relies not only its nitrogen content but also on other constituents such as amino acids, their availability, mode of digestibility, and physiological utilization of specific amino acid after ingestion by the birds (Bryden et al., 2000; Bryden and $\mathrm{Li}, 2003$ ). As is observed from the formulation data herein this study, the crude fibre content of the supplemented diet appeared to be a bit higher than the basal diet which might influence the AAs digestibility of broiler chicken. Le Goff and Noblet (2001) reported that most of the variation in digestibility of nutrients is related to the presence of dietary fibre of the feed. However, it is difficult to say truly that what factors are actually responsible for the variation of digestibility between two diets as it is a novel work, and so no data are available regarding this experiment. However, it can be assumed that the differences in AAs digestibility between the two diets could be attributed by differences in nutrient profile, characteristic of proteins, level of anti-nutritive factors, the physical and chemical composition of protein, diet characteristics, nature of protein and amino acids, fibre contents, biological value, processing method, bird age, bird per se, strain etc. (Singh and Panda, 1992; Mahmoudnia et al., 2011; Pirgozliev et al., 2011; Hossainet al., 2011, 2013, 2014).

Table 3. Apparent ileal gross energy (GE), crude protein (CP) and amino acids (AAs) digestibility of broiler chickens fed supplemented or test diet on 21 days

\begin{tabular}{lcrrrrrrrrr}
\hline \multirow{2}{*}{ Treatment } & \multicolumn{2}{c}{ Energy \& protein } & \multicolumn{10}{c}{ AAs } \\
\cline { 6 - 11 } & GE & CP & Asp & Ser & Glu & Gly & His & Arg & Thr & Ala \\
\hline $\mathrm{T}_{1}$ & 0.75 & 0.84 & $0.82^{\mathrm{a}}$ & $0.82^{\mathrm{a}}$ & $0.87^{\mathrm{a}}$ & 0.81 & $0.85^{\mathrm{a}}$ & $0.88^{\mathrm{a}}$ & 0.83 & $0.83^{\mathrm{a}}$ \\
$\mathrm{T}_{2}$ & 0.73 & 0.82 & $0.74^{\mathrm{b}}$ & $0.73^{\mathrm{b}}$ & $0.80^{\mathrm{b}}$ & 0.76 & $0.81^{\mathrm{b}}$ & $0.85^{\mathrm{b}}$ & 0.79 & $0.75^{\mathrm{b}}$ \\
$\mathrm{SEM}$ & 0.014 & 0.012 & 0.022 & 0.019 & 0.015 & 0.018 & 0.013 & 0.009 & 0.015 & 0.023 \\
P-value & 0.413 & 0.208 & 0.05 & 0.01 & 0.01 & 0.13 & 0.046 & 0.044 & 0.210 & 0.043 \\
\hline
\end{tabular}

\begin{tabular}{lccccccccc}
\hline Treatment & Pro & Cys & Tyr & Val & Met & Lys & Ile & Leu & Phe \\
\hline $\mathrm{T}_{1}$ & $0.83^{\mathrm{a}}$ & 0.83 & $0.85^{\mathrm{a}}$ & 0.82 & $0.85^{\mathrm{b}}$ & $0.92^{\mathrm{a}}$ & 0.83 & 0.83 & 0.84 \\
$\mathrm{~T}_{2}$ & $0.78^{\mathrm{b}}$ & 0.76 & $0.78^{\mathrm{b}}$ & 0.79 & $0.95^{\mathrm{a}}$ & $0.87^{\mathrm{b}}$ & 0.79 & 0.81 & 0.80 \\
$\mathrm{SEM}$ & 0.015 & 0.037 & 0.017 & 0.017 & 0.017 & 0.008 & 0.016 & 0.014 & 0.015 \\
P-value & 0.05 & 0.202 & 0.01 & 0.191 & 0.01 & 0.01 & 0.121 & 0.22 & 0.083 \\
\hline
\end{tabular}

[Each value refers to mean value of six replicates consisting of three birds per replicate cage on 21d; ${ }^{a b}$ Means bearing uncommon superscripts within a row are significantly different at $* P<0.05$ and $* * P<0.01$; GE, gross energy; $\mathrm{CP}$, crude protein; Asp, aspartic acid;Ser, serine;Glu, glutamic acid;Gly, glysine; His, histidine; Arg, arginine; Ala, alanine; Pro, proline; Cys, cysteine; Tyr, tyrosine; Val, valine; Met, methionine; Lys, lysine; Ile, iso-leucine; Leu, leucine;Phe, phenylalanine] 


\section{Conclusion}

Birds fed on protein supplemented diet responded negatively as a result of impaired feed consumption, body growth, feed conversion ratio and poor nutrient (AAs) digestibility of the broiler chickens. Although birds had a negative responses on the current level of protein supplement in the diet, further study may be

\section{References}

Ammerman CB (1995). Methods for Estimation of Mineral Bioavailability. In: Bioavailability of Nutrients for Animals: Amino Acids, Minerals and Vitamins,

Ammerman $\mathrm{CB}$, DH Baker and AJ Lewis (Eds.). Academic Press, New York, USA., pp: 83-94.

AOAC (2000). Official Methods of Analysis. 17th ed.Assoc. Official Analytical Chemist, Arlington, VA.

Awad EA, Zulkifli, AS Farjam, LT Chwen, MA Hossain and A Aljuobori (2016). Effect of low- protein diet, gender and age on the apparent ileal amino acid digestibility in broiler chickens raised under hot-humid tropical condition. The Indian Journal of Animal Sciences, 86 :696701.

Applegate TJ, SA Adedokun, O Adeola, CM Parsons, and MS Lilburn (2008). Amino acid digestibility-methodology and application. In : Multistate Poultry Feeding Conference, Indianapolis, IN

Ahmad MH, MY Miah, MA Ali, and MA Hossain, (2006). Effect of different protein concentrates replacement of fish meal on the performance of Broiler. International Journal of Poultry Science, 5: 952-956.

Corzo A, CD McDanniel, MT Kidd, ER Miller, BB Boren and BI Fancher (2004). Impact of dietary amino acid concentration on growth carcass yield, and uniformity of broilers. Australian Journal of Agricultural Research, 55: 11331138.

Cruze VC, AC Pezzato, DF Pinheiro, JC Goncalves and JR Sartori (2005). Effects of free-choice feeding on the performance and ileal digestibility of nutrients in broilers. Brazilian Journal of Poultry Science, 7:143-150.

Garcia AR, AB Batal and NM Dale ( 2007). A comparison of methods to determine amino acid digestibility of feed ingredients for chickens. Poultry Science 86: 94-101.

Hossain MA, KB Suvo and MM Islam (2011). Performance and economic suitability of three fast- growing broiler strains raised under farming condition in Bangladesh. International Journal of Agricultural Research, Innovation.\& Technology, (1\&2): 37-43.

Hossain MA, AF Islam and PA Iji (2015). The availability or retention of micronutrient contents in the ileal digesta of broiler chickens undertaken to observe the different level of high protein supplement (Pro-EL) inclusion in poultry diet and its productivity including suitability.

\section{Acknowledgement}

The authors are greatly acknowledged for the funding and executing the project by the ITA, UPM, Serdang, Malaysia

raised on plant protein diets with and without supplemental enzymes. Global Journal of Animal Scientific Research, 3: 423-434.

Hossain MA, AF Islam and PA Iji (2014). Impact of microbial enzymes on growth performance, micronutrient digestibility, tissue protein contents and endogenous enzymes activities of broiler chickens fed on vegetable protein diets. International Journal of Poultry Science, 13: 555-561.

Hossain MA, PA Iji and AFMF Islam (2016). Gross responses and apparent ileal digestibility of amino acid and mineral in broiler chickens fed vegetable-based starter diets supplemented with microbial enzymes. Turkish Journal of Veterinary and Animal Sciences ,40:583-589.

Hossain MA, MM Islam, AFMF Islam and PA Iji (2011). Constraints to use of all vegetable feed ingredients and strategies to improve such diets for poultry bird: A Review. Bangladesh Research Publication Journal, 6: 120-135.

Hossain MA, AF Islam and PA Iji (2013). Growth responses, excreta quality, nutrient digestibility, bone development and meat yield traits of broiler chickens fed on vegetable or animal protein diets. South African Journal of Animal Science, 43:208218.

Hossain MA (2013). Improving vegetable protein diets for broiler chickens. Ph.D Thesis, UNE, Australia.

Jackson S, JD Summers and S Leeson (1982). Effect of dietary protein and energy on broiler performance and production costs. Poultry Science, 61: 2232-2240.

LeGoff G and J Noblet (2001). Comparative digestibility of dietary energy and nutrients in growing pigs and adult sows. Journal of Animal Science, 79, 2418-2427.

Mahmoudnia N, F Boldaji, B Dastar and S Zereharan (2011). Nutritional evaluation of poultry byproduct meal in broiler chickens. Animal Biology \& Animal Husbandry- International Journal of the Bioflux Society, 3: 55-64.

May JD, BD Lott and JD Simons (1998). The effect of environmental temperature and body weight on growth rate and feed: gain of male broilers. Poultry Science, 77: 499-501. 
NRC (1994). Nutrient requirements of poultry. 9th ed. National Academy Press, Washington D.C.

Noreen MU (2006). Determination of nutrient digestibility and amino acids availability of various feed ingredients for Labeo rohita. Ph. D thesis, University of Agriculture, Faisalabad, Pakistan.

Pirgozliev V, MR Bedford, T Acamovic, P Mares and $M$ Allymehr (2011). The effects of supplementary bacterial phytase on dietary energy and total tract amino acid digestibility when fed to young chickens. British Poultry Science, 52: 245- 254.
Short FJ, P Gorton, J Wiseman and KN Boorma (1996). Determination of titanium dioxide added as an marker in chicken digestibility studies. Animal Feed Science and Technology, $59: 215-221$.

Singh KS and B Panda (1992). Poultry Nutrition. Kalyani Publishers, New Delhi, India, pp. 5761.

Strydom DJ and SA Cohen (1994). Comparison of amino acid analyses by phenyl isothiocyanate and 6-aminoquinolyl-N-hydroxy succinimidyl carbamate precolumn derivatization. Analytical Biochemistry, 222: 19-28. 